\title{
The Case of Lionfish (Pterois miles) in the Mediterranean Sea Demonstrates Limitations in EU Legislation to Address Marine Biological Invasions
}

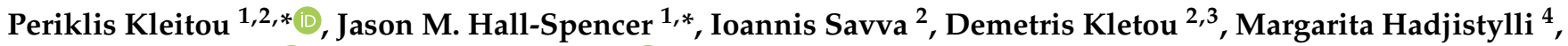 \\ Ernesto Azzurro ${ }^{5,6}{ }^{D}$, Stelios Katsanevakis ${ }^{7}$ D , Charalampos Antoniou ${ }^{2}$, Louis Hadjioannou ${ }^{8}$, Niki Chartosia ${ }^{9}$, \\ Maria Christou ${ }^{2}$, Yiannis Christodoulides ${ }^{4,8}$, Ioannis Giovos ${ }^{2,10}$, Carlos Jimenez ${ }^{8}$ (D), Sonia Smeraldo ${ }^{6}$ \\ and Siân E. Rees 1
}

check for updates

Citation: Kleitou, P.; Hall-Spencer, J.M.; Savva, I.; Kletou, D.; Hadjistylli, M.; Azzurro, E.; Katsanevakis, S.; Antoniou, C.; Hadjioannou, L.; Chartosia, N.; et al. The Case of Lionfish (Pterois miles) in the Mediterranean Sea Demonstrates Limitations in EU Legislation to Address Marine Biological Invasions. J. Mar. Sci. Eng. 2021, 9, 325. https://doi.org/10.3390/jmse9030325

Academic Editors: Gualtiero Basilone and Caterina Faggio

Received: 14 February 2021

Accepted: 12 March 2021

Published: 15 March 2021

Publisher's Note: MDPI stays neutral with regard to jurisdictional claims in published maps and institutional affiliations.

Copyright: (C) 2021 by the authors. Licensee MDPI, Basel, Switzerland. This article is an open access article distributed under the terms and conditions of the Creative Commons Attribution (CC BY) license (https:/ / creativecommons.org/licenses/by/ $4.0 /)$.
1 School of Biological and Marine Sciences, University of Plymouth, Plymouth PL4 8AA, UK; sian.rees@plymouth.ac.uk

2 Marine and Environmental Research (MER) Lab., Limassol 4533, Cyprus; isavva@merresearch.com (I.S.); dkletou@merresearch.com (D.K.); cantoniou@merresearch.com (C.A.); maria.ch.christou@gmail.com (M.C.); igiovos@merresearch.com (I.G.)

3 Department of Maritime Transport and Commerce, Frederick University, Limassol 3080, Cyprus

4 Department of Environment, Ministry of Agriculture, Rural Development and Environment, Nicosia 2432, Cyprus; MHadjistylli@environment.moa.gov.cy (M.H.);

ychristodoulides@environment.moa.gov.cy (Y.C.)

5 National Research Council, Institute of Marine Biological Resources and Biotechnologies, 60125 Ancona, Italy; eazzurr@gmail.com

6 Stazione Zoologica Anton Dohrn, Villa Comunale, 80121 Naples, Italy; sonia5.6.89@hotmail.it

7 Department of Marine Sciences, University of the Aegean, 81100 Mytilene, Greece; stelios@katsanevakis.com

8 Enalia Physis Environmental Research Centre, Nicosia 2101, Cyprus;

1.hadjioannou@enaliaphysis.org.cy (L.H.); c.jimenez@enaliaphysis.org.cy (C.J.)

9 Department of Biological Sciences, University of Cyprus, Nicosia 1678, Cyprus; chartosia.niki@ucy.ac.cy

10 iSea, Environmental Organisation for the Preservation of the Aquatic Ecosystems, 54645 Thessaloniki, Greece

* Correspondence: pkleitou@merresearch.com (P.K.); jhall-spencer@plymouth.ac.uk (J.M.H.-S.); Tel.: +357-9659-8310 (P.K.); +44-175-258-4629 (J.M.H.-S.)

Abstract: The European Regulation (EU) 1143/2014 on Invasive Alien Species entered into force in 2015 , with the aim to fulfill regional and international biodiversity goals in a concerted manner. To date, the Regulation listed 66 Invasive Alien Species (IAS) that are subject to legal controls. Only one of these is marine. A recent lionfish (Pterois miles) invasion has been closely monitored in the Mediterranean and a detailed risk assessment was made about the profound impacts that this invasive fish is likely to have on the fisheries and biodiversity of the region. In 2016-21, lionfish rapidly became dominant predators along Eastern Mediterranean coasts, yet the process for their inclusion on the EU IAS list has been lengthy and is ongoing. There is an urgent need to learn from this experience. Here, we recommend improvements to the Regulation 1143/2014 and the risk assessment process to protect marine ecosystems and secure the jobs of people that rely on coastal resources.

Keywords: invasive species; alien species; non-indigenous species; Lessepsian; risk assessment; Regulation 1143; recommendations; management; control; early response

\section{Introduction}

Globalization and intensification of human activities are driving an accelerating number of non-indigenous species (NIS, also known as alien, exotic, introduced, or non-native species) to areas beyond their natural ranges, reshaping local communities and altering ecosystem services [1,2]. A subset of NIS, known as invasive alien species (IAS), have harmful impacts on the economy, environment, and health of the recipient ecosystem [3]. They 
are one of the primary threats to global biodiversity and human livelihoods [4,5]. Europe is heavily affected by NIS with over 13,000 alien or cryptogenic taxa currently reported in the European Alien Species Information Network [6,7]. Quantitative simulations on future trajectories until 2050, have projected that Europe will face the highest continental increases $(+2543 \pm 237)$ of established NIS [8]. Even moderate increases are expected to cause major impacts on most socioecological contexts, and these can be mitigated only if rapid and comprehensive actions are taken [9].

As invasive species are numerous, it would be impossible to adopt dedicated measures against all. In 2014, Europe adopted an innovative and ambitious legislation on IAS (EU Regulation no.1143/2014; hereafter: IAS Regulation) that represents a major advance towards a coordinated and harmonized procedure for IAS management [10]. The IAS Regulation came into force in 2015 to fulfill international and regional legislation such as the Action 16 of Target 5 of the EU 2020 Biodiversity Strategy, and the Aichi Target 9 of the Strategic Plan for Biodiversity 2011-2020 under the Convention of Biological Diversity. Its importance is highlighted in the EU Biodiversity Strategy for 2030, which states that the IAS Regulation must be stepped up "to minimize, and where possible eliminate, the introduction and establishment of alien species in the EU environment" [11].

At the core of this legislation, the list of IAS of Union concern ("the Union list") identifies species whose adverse impact requires concerted action at a Union level. The need for concerted action must be demonstrated through a detailed risk assessment (Article 5.1), while socio-economic aspects to ensure that disproportionate or excessive costs will be avoided need to also be considered. Species that are included in the Union list are subject to stringent provisions for prevention, early detection and rapid eradication, and management. The import, transit within the Union, trade, possession, breeding, transport, use, and release into the environment are restricted (Article 7). European member states are obliged to identify the pathways which require priority action for the IAS of Union concern and then establish and implement at least a single action plan to address those pathways (Article 13). Moreover, member states are obliged to establish a surveillance system for the IAS of concern (Article 14), immediately attempt eradication at an early stage of their invasion (Article 17), or place effective management measures to minimize the spread and impacts of already established IAS (Article 19).

The IAS Regulation departed from traditional approaches and set a precautionary, yet challenging approach towards IAS management [12]. The first years of its implementation offered critical insights and opportunities for improvement. A noteworthy case is the disproportionately low presence of marine species on the Union list, which does not fully acknowledge or address the threat they pose to the EU marine environment [13]. European Seas host the highest number of NIS worldwide with over 800 taxa considered as established [14]. The majority of these NIS are found in the Mediterranean Sea where they are spreading rapidly while indigenous species are declining, thus impairing the function, structure, and integrity of the marine ecosystems [15-18]. In the eastern Mediterranean, NIS together with climate change are driving biodiversity collapse [19]. However, only one marine species, Plotosus lineatus (Thunberg, 1787) is currently included on the IAS Union list [13], which includes 66 terrestrial and freshwater NIS (EC/2019/1262).

A marine species currently under consideration by the EU for inclusion on the Union list is the lionfish, Pterois miles (Bennett, 1828), first reported in the Mediterranean Sea in 2012 from Lebanon [20] after an unsuccessful invasion attempt in 1991 [21]. Lionfish quickly became established in the Levantine [22,23] and spread towards the central Mediterranean [24,25], demonstrating one of the fastest fish invasions ever reported in the region. The species was already involved in a major invasion of tropical and subtropical habitats in the western Atlantic basin [26]. Due to its documented invasion history, an EU horizonscanning exercise concerning new or emerging species ranked lionfish as second on a list of 95 species that should be prioritized for risk assessment [27].

To respond swiftly to this invasion of the Mediterranean Sea, the European Union funded the RELIONMED project, through the EU Commission's LIFE programme 2014-2020 
(LIFE16 NAT/CY/000832) that aimed to make Cyprus the first line of defense against the invasion [28]. The project aims to address the invasion at an early stage, collect the necessary data, and guide concerted actions against the lionfish (P. miles) management in the basin by adding the species to the Union list.

In this document, we (1) present the RELIONMED efforts to collect early-invasion data and propose lionfish Pterois miles for inclusion to the Union list; (2) document lessons learnt from this effort; and (3) provide recommendations on the basic IAS Regulation and the Delegated Regulation on risk assessments 2018/968 that could be applied to improve relevance, coverage, effectiveness, and management of marine IAS at a European and regional level.

\section{The Lionfish (Pterois miles) Invasion History}

The native range of Pterois miles (Figure 1) is restricted to the Indian Ocean, specifically from the Red Sea all the way down to eastern South Africa, including the Arabian Sea, Persian Gulf, Gulf of Oman, Laccadive Sea, Bay of Bengal, Andaman Sea, and Indonesian region [29]. Around Indonesia, P. miles population overlaps with the congeneric Pterois volitans and Pterois russelii. Pterois miles, and P. volitans (known as lionfish complex) invaded the North-western Atlantic in late 1980s and expanded throughout the region, northwards along the east coast of the USA reaching as far as Rhode Island, eastwards to Bermuda, and southwards throughout the Gulf of Mexico, Central America, South America, Caribbean, and Brazil [30,31]. Several biological and ecological traits have contributed to their invasion success including, an opportunistic predator and generalist diet [32,33], anatomical, and physiological traits that optimize its feeding strategy [34,35], defensive venomous spines [36], rapid maturity [37], iteroparous, broadcast and highly fecund spawning [30], and a pelagic larval phase that allows dispersion of larvae across great distances for about 20-35 days [38].

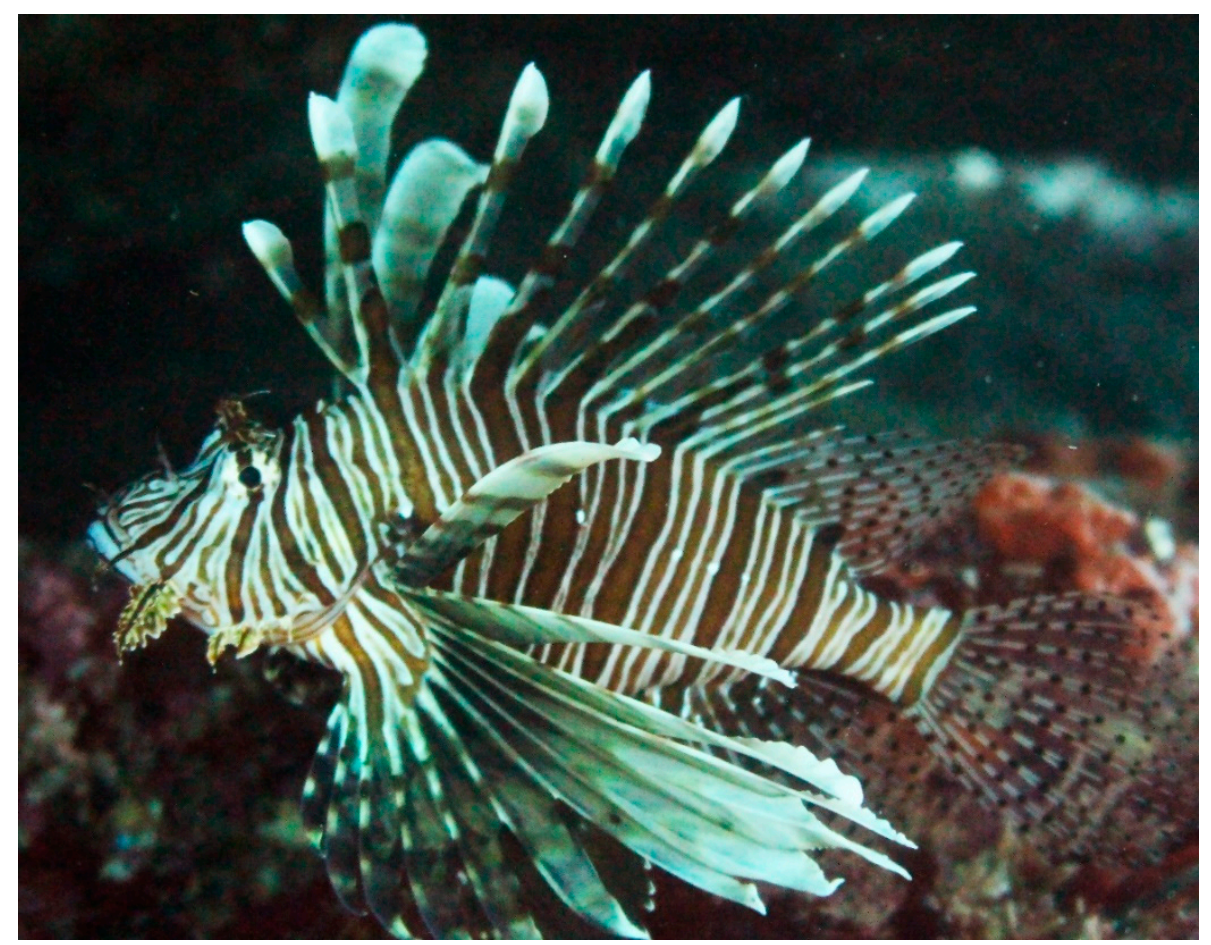

Figure 1. A lionfish (Pterois miles) individual photographed at the reefs of the Cavo Greco (Cyprus) Marine Protected Area in May 2019.

Despite having intermediate consumption rates, the higher densities and catch efficiency of lionfish has resulted in high impacts to the local biodiversity [39]. Numerous studies from the Western Atlantic have demonstrated that an increase in lionfish abundance 
can lead to a significant decline in the recruitment, biomass, and abundance of local fish species [40-44]; with the impacts felt at a regional level [45]. At some invaded sites there have been reports of up to $95 \%$ reduction in abundance of small native species [41]. Apart from direct impacts on local fish communities, lionfish were found capable to drive an overall shift in invertebrate assemblage composition, [46] and shift sites to algal-dominated habitats through predation on herbivorous reef fishes [47-49]. Using an ecological model that uses prey consumption and biomass production, Green et al. [50] suggested that predation effects of lionfish are nonlinear but begin to occur beyond a particular threshold of predation mortality, thus impacting on communities with high biomass are unlikely under low lionfish densities.

\section{Proposal of Lionfish for Inclusion to the Union List}

\subsection{Data Collection and Species Proposal}

The RELIONMED proposal was submitted in September 2016, when lionfish populations were still limited and restricted to the eastern Mediterranean. In 2017, the four-year project was accepted for funding and successfully initiated in September 2017. The early project actions aimed to cover the elements of the risk assessment as specified in the Article 5(1) of the IAS Regulation and the delegated Regulation (EU) 2018/968. These elements include organism information, native and alien distribution, pathways and probability of introduction, probability of establishment and spread under present and future climatic conditions, and magnitude of impacts (on biodiversity, ecosystems, ecosystem services, socio-economy, and human health).

Under the RELIONMED project actions, lionfish specimens were collected and examined; taxonomic identity and pathway of introduction were studied using molecular analyses; growth rates were estimated based on otoliths; reproduction was investigated by studying gonads; and foraging behavior and potential impacts to local biota were analyzed through stomach contents examination. (More details on the methodologies can be found in (More details on the methodologies can be found in [51,52]). The introduction patterns of lionfish under different environmental conditions were analyzed using observations by citizen-scientists $[28,51]$, while questionnaire surveys were conducted targeting the general public and stakeholders to elucidate known uses of lionfish in the market, as well as perceptions and knowledge about the invasion [53]. To cover information on the risk management (Article 4(3)(e) and Article 4(6)), the efficiency of targeted lionfish removals was monitored through ecological and socioeconomic surveys to assess the costs of removals relative to the cost of inaction from social and economic points of view.

Results of the project were compiled with data from the literature to produce a comprehensive risk assessment together with evidence for the cost-effectiveness of the species management. The scoring and classification for the risk assessment evaluations were based on a combination of protocols as suggested by the EU (Supplementary Material 1). Possible measures to manage the lionfish invasion in the Mediterranean Sea were identified for (i) prevention, (ii) eradication, and (iii) long term control. Both documents were peer-reviewed by two independent scientists before submission to the EC in February 2019. Following review by the Scientific Forum of the EU and comments by stakeholders, a revised risk assessment was submitted in 2020. The submissions were deemed by the Scientific Forum as robust and fit-for-purpose in November 2020, and the species inclusion will be brought for discussion to the IAS Committee with a view to be screened against the criteria of Article 4(3), with due consideration to Article 4(6) in June 2021.

\subsection{Results of the Lionfish Risk and Management Assessments}

The results of this effort have confirmed the imminent threats of the lionfish invasion in the Mediterranean and identified potential management measures that could be applied to limit the potential damages.

The risk assessment concluded with high confidence that there is a high degree of risk (social, ecological, and economic) associated with the future spread of lionfish in the 
Mediterranean and the European Union. Most notably, in the years from the first sighting to submission of the risk assessment, lionfish were able to rapidly spread and establish in the entire Levantine Sea, southern and central Aegean Sea, Greek Ionian Sea, and reach Tunisia and Italy $[22,24,25,54]$. This demonstrates one of the fastest fish invasions ever reported in the eastern Mediterranean Sea [55] (Figures 2 and 3; Supplementary Material 2). The reported lionfish sightings by citizen scientists (sea users, divers, fishers, etc.) of count (number of reports) and density observed (number of lionfish individuals) have increased substantially over these years; from 1 to 3 individuals to over 50 observed in a single day (Figures 2 and 3; Supplementary Material 2). Indicatively, over 300 lionfish were removed from three single-day eradication events in 2019-2020 from small areas (about two hectares) within Cyprus Marine Protected Areas (RELIONMED data).

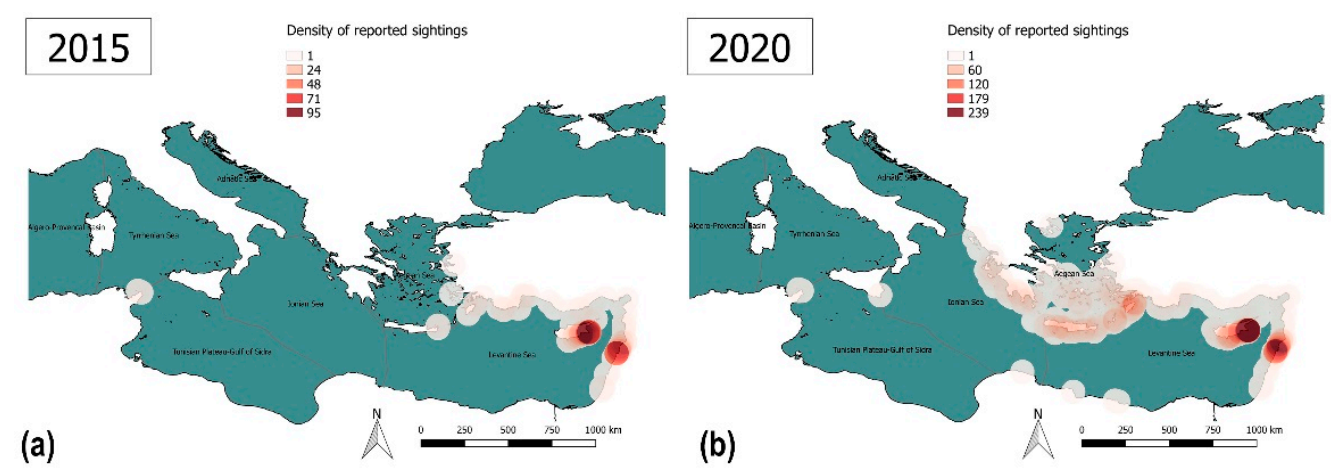

Figure 2. Heat map of the density of the reported lionfish sightings in the literature and authors' datasets (radius $=70 \mathrm{~km}$ ) in (a) 2015 and (b) 2020 (the dataset is available in Supplementary Material 2).

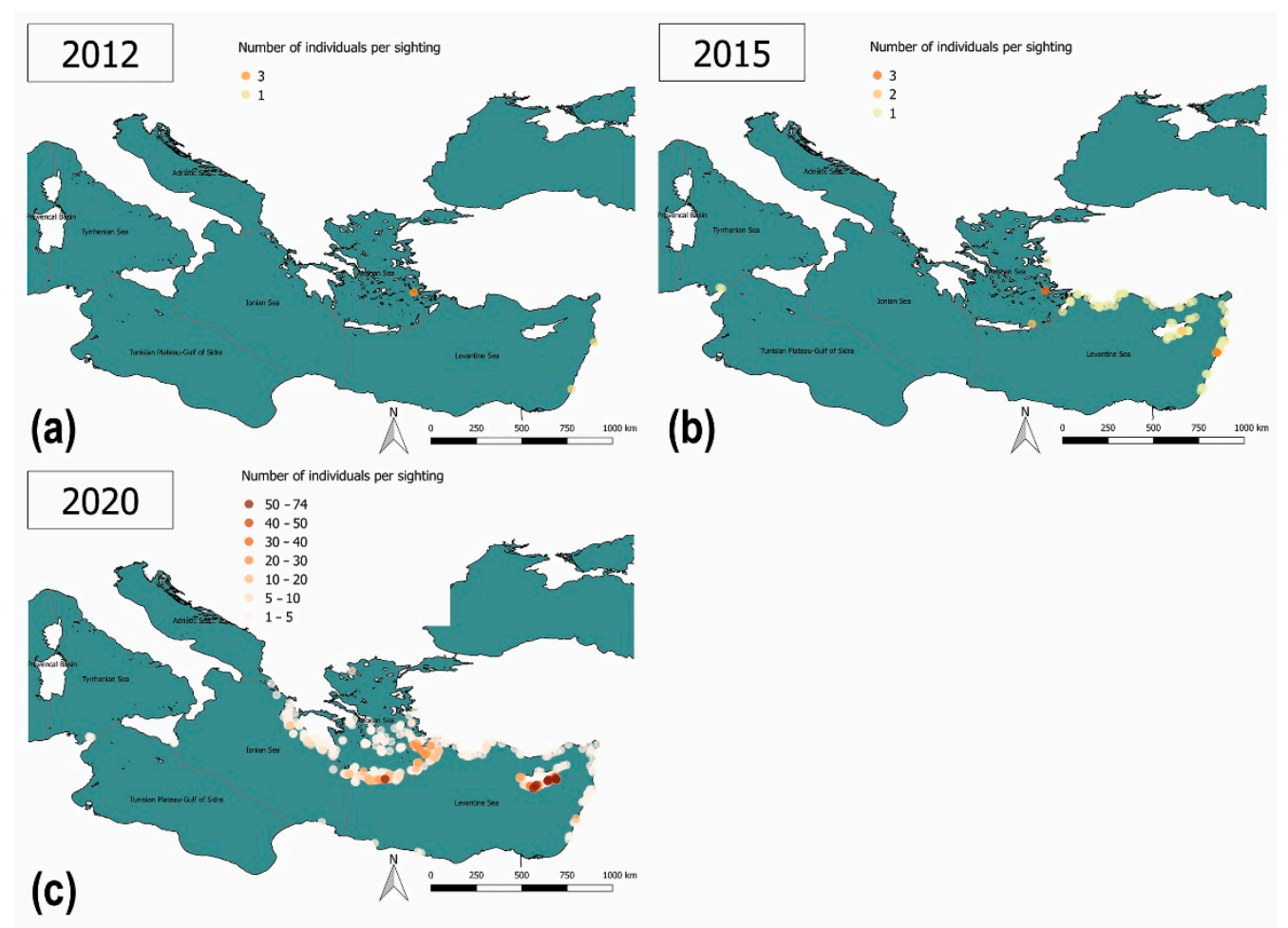

Figure 3. Number of individuals observed per sighting for (a) 2012, (b) 2015, and (c) 2015. The dataset is available in Supplementary Material 2.

In the Mediterranean, lionfish are mostly found on rocky substrata, followed by seagrass (Posidonia oceanica) meadows [51], and they are also able to occupy deep-water 
habitats [56] including Dendrophyllia ramea coral communities at 130-150 m depth [57]. The biological studies conducted in the Mediterranean have shown that lionfish have characteristics that are typical of invasive success such as early maturity, rapid growth rates, generalist predation behavior, lack of natural predators, and naïve prey [51,58-60].

The most relevant introduction pathways that were identified were (a) Corridor (Interconnected waterways/basins/seas-Suez Canal), (b) Release in nature (other intentional release-aquarium hobbyist), and (c) Transport-Stowaway (Ship/boat ballast water). The Suez Canal, as confirmed by genetic studies, is the major pathway of lionfish introduction in the basin $[25,61,62]$. Natural dispersal of lionfish has been identified as the major pathway of spread within the Mediterranean, but other introduction pathways could enhance its genetic diversity and also facilitate its spread.

There is uncertainty about how far the species will spread under current and projected climate change. Species Distribution Models (SDMs) have been inaccurate in predicting lionfish Mediterranean hotspot areas (e.g., [63]), likely due to climatic niche expansion (i.e., the environmental shift of species beyond their climatic limits in their native ranges) and the presence of a favorable climate in the invaded domain not yet occupied by the species [55,64]. Assessments of the future spread and impact of lionfish in the Mediterranean were conducted in two ways: (a) a conservative approach, based on an ensemble of Species Distribution Models, projected that lionfish will remain restricted to the eastern Mediterranean under projected climate change scenarios [55,65], and (b) assuming that lionfish are only limited by the winter isotherm of $15{ }^{\circ} \mathrm{C}$, as is the case in North Carolina (USA) $[25,66]$. Using the latter method, lionfish were expected to spread to the western Mediterranean Sea and southern Iberian coast under current climatic conditions, and towards the Adriatic Sea, Bay of Biscay, and Macaronesia, according with the predicted climate change (Representative Concentration Pathway scenario 6.0) (see Ch2. in Supplementary Material 1).

The magnitude of impacts on biodiversity, ecosystem services, economy, and human health are thought to be "major" to "massive" but with medium confidence in the evidence used to underpin the assessment. Despite certainty about the impacts of lionfish on ecology, economy, and human wellbeing in the western Atlantic [40-44,46-49], limited information was available about the effects of the invasion in the Mediterranean Sea. Therefore, most assessments about the potential impacts of lionfish at the European scale were scored with low confidence (Figure 4; Section "Magnitude of Impact" in Supplementary Material 1). The assessments anticipate that lionfish impacts exacerbate under climate change scenarios (Supplementary Material 1).

Options for Risk Management (Supplementary Material 3) identified three prevention, three eradication, and seven management measures that could be used to limit the ecological and socioeconomic losses caused by the lionfish invasion in the Mediterranean (Supplementary Material 3). The application of prevention measures could limit the genetic diversity of lionfish in the Mediterranean and prevent facilitation of lionfish spread within the basin; thus, they were promoted where cost-effective. Since the invasion is already well underway, eradication measures will have little success and could focus only in areas where lionfish are at a very early stage of invasion, and populations are still very limited. As regards to management/control measures, it was shown that diver-led culling can be effective to control lionfish in priority areas; however, legislative framework changes would be needed to allow removal events though scuba diving. Citizen science monitoring, dissemination of science-based knowledge, and market promotion of the lionfish were all found to be low-cost actions with a great potential for managing the lionfish invasion and they would deserve to be supported and properly coordinated at the regional or sub-regional level. Moreover, the implementation of these actions would offer important benefits (e.g., engagement of local communities, regular monitoring, and adaptive management) for dealing with other invasive species too. New removal/fishery techniques such as lionfish specific traps [67] and underwater robotics [68] hold potential but need development and test- 
ing in Europe and potentially legislation changes to enable their use. Fishery reforms that could be used to tackle lionfish and other marine species in the Mediterranean were elaborated by Kleitou et al. [69].

The full risk assessment and risk management documents can be found in Supplementary Material 1 and Supplementary Material 3, respectively.

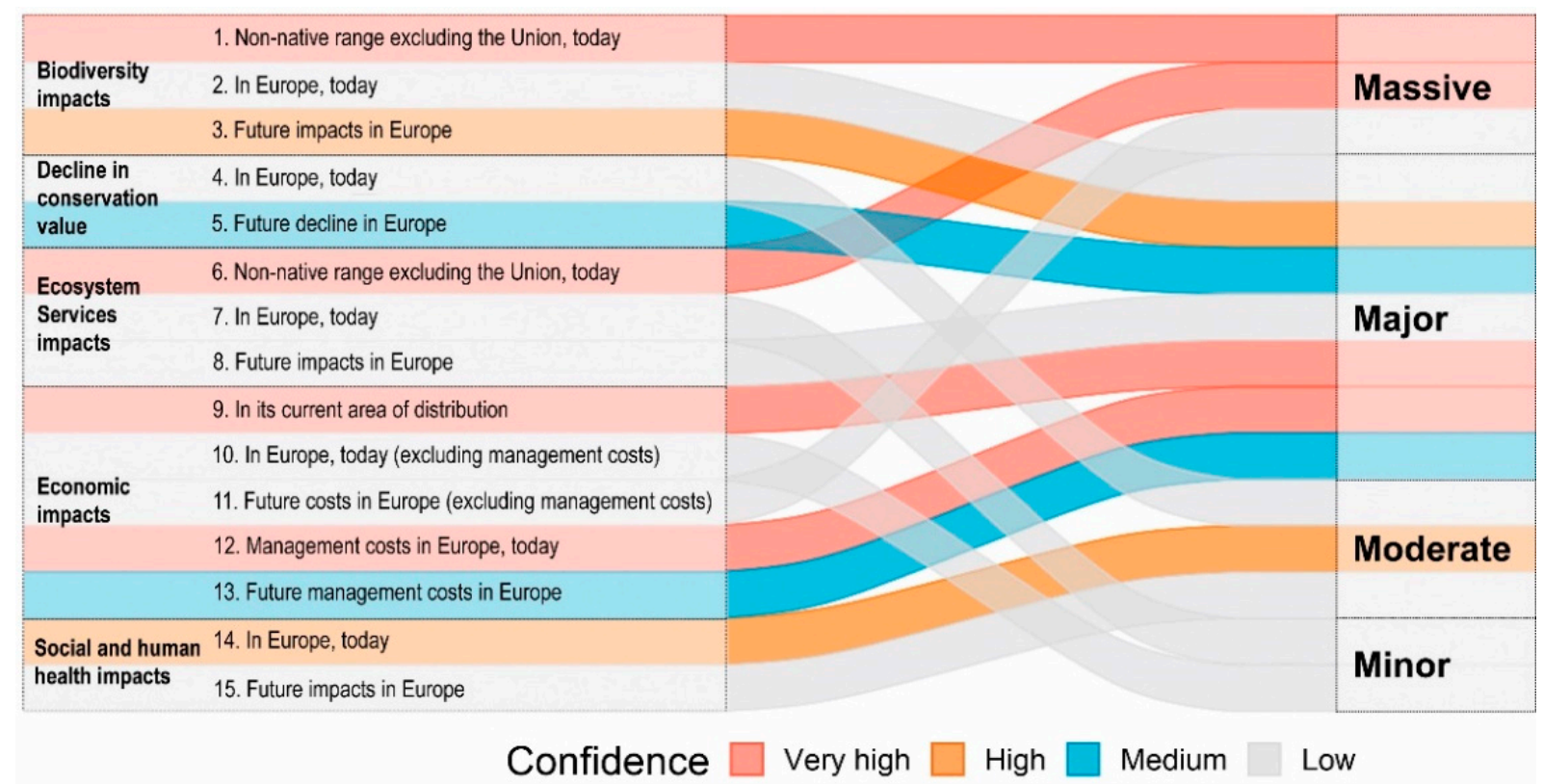

Figure 4. Assessment of lionfish current and future impacts on (i) biodiversity (at all levels of organization, e.g., decline in native species, changes in native species communities, hybridization), (ii) conservation value with regard to European and national nature conservation legislation, (iii) economy, (iv) ecosystem services (provisioning, regulating, and cultural services), and (v) society and human health, using the evaluation scheme shown in Supplementary Material 1.

\subsection{Insights and Recommendations for the IAS Regulation}

The process undertaken for the inclusion of lionfish on the Union list extracted many insights and highlighted limitations of the IAS Regulation, particularly with respect to marine species, justifying the disproportionately low presence of marine species in the list of IAS of Union concern [13]. These include the need to demonstrate the threat in the absence of sufficient ecological and socioeconomic data, limited involvement by non-member states, unchallenged primary pathways of invasion (mainly through the Suez Canal), lengthy evaluation processes, and need for adaptive management of marine species (Table 1). Identifying the limitations in these first years of the IAS Regulation implementation are crucial towards an improved Post-2020 framework on IAS. In Table 1, we summarize the major challenges and recommendations that could be used to improve and streamline the EU legislation against IAS, and we discuss each point further below. 
Table 1. Overview of challenges identified from the lionfish invasion in the Mediterranean and recommendations to improve EU Regulation and implementation against marine invasive alien species (IAS).

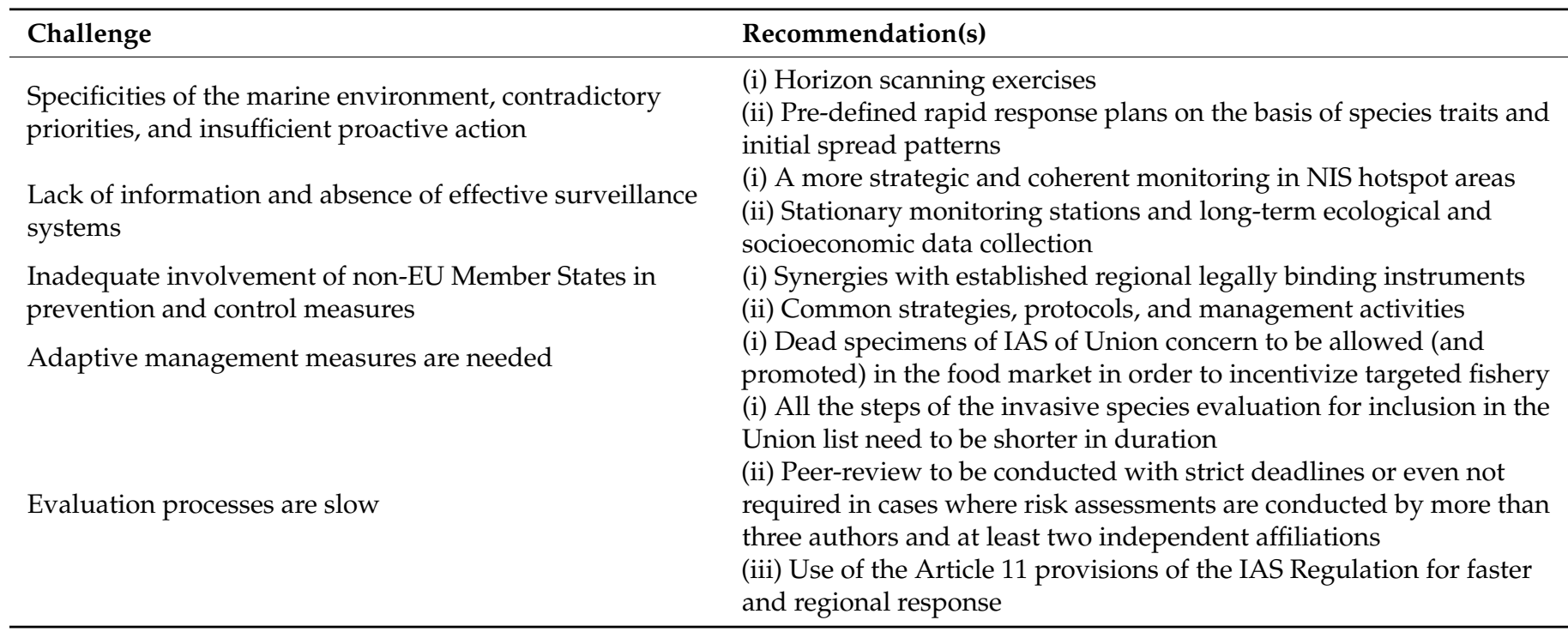

3.3.1. Specificities of the Marine Environment, Contradictory Priorities, and Insufficient Proactive Action

The IAS Regulation encompasses all taxonomic groups and habitats within a single instrument, which does not acknowledge, nor address the fundamental differences between terrestrial and marine systems. Measures on banning sales and border controls on imported goods and travelers, while crucial for preventing terrestrial invasions (particularly traded plans and animals), and while indeed recognized as a key strength of the IAS Regulation, are meaningless for the marine environment. Importantly, the transport of organisms in the connective aquatic medium by the convective forces of ocean currents significantly surpasses, in magnitude and rate, the potential for propagule dispersal in terrestrial ecosystems $[70,71]$. Indicatively, lionfish larvae are able to disperse across great distances for about 20-35 days before they settle to benthic habitats [38]. Habitat corridors, natural barriers and discontinuities have little effect on marine organisms compared to their terrestrial counterparts, especially on those with a pelagic or biphasic life cycle $[70,72]$.

From an applied perspective, higher dispersal capacity increases the speed of changes, decreases the time available for rapid management response, and challenges the effectiveness of long-term management, necessitating faster reaction and stronger cross-border cooperation. Eradication of marine invasive species has rarely been achieved and only in restricted areas following early detection and rapid response (e.g., [73,74]).

The IAS Regulation acknowledges that prevention is more environmentally desirable and cost-effective than reaction after the introduction of an IAS and should therefore be prioritized. Accordingly, priority is given to species that are not yet present in the Union or are at an early stage of invasion. Indeed, the control of marine invasive species is more likely to succeed if a species detection and management response is fast [75]. However, IAS can be listed in the Union list only if they meet the criteria mentioned in Article 4 (Paragraph 3), including that "they are, based on available scientific evidence, likely to have a significant adverse impact on biodiversity or the related ecosystem services, and may also have an adverse impact on human health or the economy", and that "it is likely that the inclusion on the Union list will effectively prevent, minimize or mitigate their adverse impact". "An IAS should be considered to be of Union concern if the damage that it causes in affected Member States is so significant that it justifies the adoption of dedicated measures applicable across the Union".

The criteria of the IAS Regulation can be viewed as contradictory to a proactive approach where prevention and/or early eradication are prioritized. They are compatible 
with a reactive approach, where countries need to first recognize the threats and show evidence that IAS policy can be turned into management actions [76]. By the time that sufficient data are available to assess the potential impacts, marine species, as exemplified by the lionfish, can spread over a vast area, making eradication unfeasible and management attempts disproportionately costly $[77,78]$.

Horizon scanning exercises, to keep a continuous overview of IAS, along with rapid on-demand site-based assessments for a specific purpose (e.g., an IAS sighting), are useful in prioritizing species and guiding proactive measures $[13,79,80]$. To further support rapid response after early detection, an improved IAS Regulation would necessitate pre-defined rapid response plans by member states, on the basis of species traits and initial spread patterns (see, e.g., [81]). This would allow rapid decision making on the appropriate actions for eradication immediately after detection, without the need of time-consuming species-specific evaluations. The rapid response plans will allow to identify where, how, on what, and when we should act, and first prioritize management actions rapidly at an early stage than can potentially control the population, and thus increase the likelihood of success [70].

\subsubsection{Lack of Information and Absence of Effective Surveillance Systems}

Despite the focus given to the Mediterranean Sea, as the most invaded marine region worldwide [14], there is still lack of standardized and harmonized monitoring throughout the basin [82] and substantial knowledge gaps for marine invasions [83]. Information on marine species distributions, ecology, and evolution is often fragmented or non-existent [84,85]. The Delegated Regulation on risk assessments (EC/2018/968) acknowledges the possibility of incomplete knowledge about a species, and the need for risk assessments to "be able to account for such lack of knowledge and information and address the high degree of uncertainty as regards the consequences of an introduction or spread of the relevant species". Indeed, the knowledge gaps on the lionfish establishment, spread, and impacts were notable, albeit the coordinated effort for rapid data collection.

The IAS Regulation highlights the importance of surveillance systems for the IAS. Specifically, it states that, "surveillance systems offer the most appropriate means for early detection of new invasive alien species and for the determination of the distribution of already established species." In addition, Member States are obliged to establish a surveillance system of IAS of Union concern, or include it in their existing system, which collects and records data for IAS or other species (Article 14 of the IAS Regulation). According to the Article 19, the surveillance system should also be designed to monitor the efficiency of management interventions in minimizing the impacts of an IAS, as well as their impacts on non-targeted species.

The absence of effective surveillance systems from the lionfish-invaded areas was identified as a major bottleneck through the process to compile the risk assessment. The development of a (i) joint instrument for data and information of alien species through the European Alien Species Information Network (EASIN) [7,86], and the (ii) monitoring conducted by Member States in the context of the European Union's Marine Strategy Framework Directive [87] are useful for providing distribution data, but lack of standardization, harmonization, and duration to enable understanding of species impacts $[87,88]$. The emergence of participatory initiatives [15,89] and citizen science have been found effective mostly in monitoring the distribution of NIS and for early detection, particularly for conspicuous taxa such as the lionfish [90-95]. Other survey methods have been found able to capture different and complementary views of an ecosystem $[96,97]$. To understand mechanisms underlying ecological patterns and impacts by NIS, a targeted and hypothesisdriven research strategy is needed [98]. Fragmented efforts by Member States, without coordination and strategic implementation, might lead to gathering futile data that cannot enhance the understanding of interactions at relevant ecosystem levels $[99,100]$.

A more strategic and coherent monitoring plan could be promoted by the EU to optimize data collection and facilitate transparent, auditable, and timely decision-making. 
The value of time-series ecological and socioeconomic data has been emphasized in conservation policy [101], but no data were available to rapidly elucidate the impacts of lionfish in the Mediterranean ecosystems. Long-term data before and after the invasion could potentially enable a better understanding of the changes caused by the invasive species, together with well-designed comparisons between affected and unaffected sites. More EU effort can be strategically placed in areas where NIS are first recorded and by accounting dispersal and colonization processes, e.g., near NIS hotspots areas, in the Levant (e.g., Cyprus) which is the first area to be affected by Lessepsian immigrations, and in harbors and marinas for ship-mediated introductions.

\subsubsection{Inadequate Involvement of Non-EU Member States in Prevention and Control Measures}

The IAS Regulation highlights that "cross-border cooperation, particularly with neighboring countries, should be fostered to contribute to its effective application." Article 22 of the IAS Regulation refers to the need for cooperation and coordination but only within the EU. Geopolitical borders do not affect the invasion of NIS and international cooperation is needed in management actions [102,103]. The Mediterranean Sea shares coastlines with 21 countries from which only seven are EU Member States. Isolative attempts from Member States to prevent introductions and/or manage IAS will likely be unsuccessful, particularly when dealing with species with high dispersal capacity.

The IAS Regulation obligates Member States to ban the intentional or negligent introduction of alive individuals of species of Union concern to avoid, as stated, situations where action taken in one Member State is undermined by inaction in another Member State. In addition, it requires all Member States to establish and implement one single action plan or a set of action plans to address the priority pathways of introductions. However, many IAS including lionfish, spread to the EU via secondary dispersal from non-EU Member States. The most important primary pathway for NIS introductions in the eastern Mediterranean is the Suez Canal in Egypt [104,105]. Propagule (e.g., larvae and eggs) pressure from neighboring countries will persist in spite of the implementation of any IAS Regulation provisions at member state level. In our management assessment (Supplementary Material 3), we highlight the importance of cooperation and enforcement of biosecurity measures in the Suez Canal. This includes the installation of a high-salinity section in the Suez Canal, reinstating the former salinity barrier of the Bitter Lakes, and/or the establishment of locks that would additionally decrease current movements and dispersal of propagules drifting to the Mediterranean. Similarly, other legislation and effort, such as the ban from the market (aquarium) for species of Union concern or the legal framework to control translocations of non-native species in aquaculture (EC/708/2007), need to be promoted regionally [106,107].

The involvement of non-EU Member States could delay IAS establishment allowing more time for response, as well as enable a more consistent, multi-vector, and coordinated approach against IAS. Synergies with established, regional, legally binding instruments (e.g., Barcelona Convention and General Fisheries Commission for the Mediterranean) can be promoted, voluntary codes of conduct can be implemented, and common strategies, protocols and management activities can be adopted at regional scales.

\subsubsection{Adaptive Management Measures Are Needed}

The IAS Regulation follows a hierarchy of management measures for prevention, early detection and rapid eradication, and lastly ongoing management. As demonstrated by the lionfish invasion, the level of quantitative data required for species to be placed in the Union list is barely available for marine species that are not already established and widespread. Therefore, measures for prevention and early response might not be adequate, and efforts are shifting to long-term management. For management measures, the IAS Regulation indicates that they shall be proportionate to the impact on the environment based on an analysis of costs and benefits. Raising public awareness and education, and encouragement of physical removal and commercial utilization have been recognized as 
few of the most low-cost but relatively effective management actions for marine IAS in the Mediterranean Sea $[69,81]$.

Article 7 of the IAS Regulation specifies that species of Union concern should not be intentionally placed on the market and that buying, selling, using, and exchanging the IAS shall be prohibited. The IAS Regulation needs to be adapted for dead specimens to be allowed (and promoted) in the food market in order to incentivize a targeted fishery and hence continuous removal from the natural environment [69,78]. Time consuming and costly processes, and preconditions associated with derogations from the fishery market/trading restrictions of marine species (e.g., that species are widespread, inclusion of measures in member states management plan, obligations for monitoring, and control of market) could be avoided to enable early and sustainable fishery pressure to IAS populations [69].

\subsubsection{Faster Evaluation Processes Are Needed}

The data collection, analyses of evidence, and the proposal of species to the Union list took years allowing lionfish populations to expand substantially (Figure 3). All the steps of the invasive species evaluation need to be shorter in duration for any rapid response to be possible. To achieve this, the Scientific Forum and stakeholders can deliver their opinions faster (e.g., a month rather than the four months as experienced in our lionfish Risk Assessment) and examine the proposals for marine species more often, thus allowing prompt (re-)submissions and minimizing the duration from the first sighting to the evaluation of the risk assessment. In addition, the Scientific Forum's final decision could be closer in date to the evaluation by the committee of representatives of the Member States. In the case of the recent lionfish risk assessment, significant time, and an annual deadline of the Commission was missed due to the need for peer-revision of the 129-page-long risk assessment. According to the Article 2 of the Delegated Regulation (EC/2018/968), a quality control process shall include at least a review of the risk assessment by two peer reviewers, and the author(s) of the risk assessment as well as the peer reviewers must be independent and have relevant scientific expertise, and not affiliated to the same institution. To limit costs, logistical difficulties, and delays, we suggest peer-review to be conducted with strict deadlines or even not required in cases where risk assessments are conducted by more than three authors, at least two independent affiliations, and represented by two different Member States.

An alternative approach to avoid lengthy risk assessment processes for adding IAS to the Union list as well as Article 7 (market) restrictions would be the use of the Article 11 provisions of the IAS Regulation. Article 11 allows member states to identify from the national list of IAS, species that require enhanced regional cooperation and establish provisional measures (e.g., Articles 13, 14, 16, 17, 19, and 20) with the support of the European Commission. The procedure is also linked to Article 22, which encourages cooperation/coordination among member states that share marine sub-regions, regarding marine species and may be enhanced through implementing acts. Although not used by any member state yet, Article 11 could offer an alternative, faster regional response and could be further promoted by the European Commission and member states.

\section{Conclusions}

The EU Invasive Alien Species Regulation is the core legislation for IAS management in Europe, and its importance is highlighted in the EU Biodiversity Strategy for 2030. However, marine species are under-represented despite posing a major socioeconomic and environmental threat in the region. Using the case of a current lionfish invasion in the Mediterranean Sea, we highlight some clear limitations of the basic Regulation 1143/2014 as well as the Delegated Regulation 2018/968 to manage the issue of marine bioinvasions in the Mediterranean region. The main issues originate from the intrinsic differences between terrestrial and marine systems, and the low consideration of marine bioinvasions in these 
regulations. This work identified and proposed several measures for improvement of the EU legislation.

The high connectivity of marine ecosystems necessitates a rapid approach. A lack of available information (both ecological and socioeconomic) emphasized the need for strategic, coordinated, and improved monitoring in sentinel locations of Europe. Efforts in the European marine sub-regions could be easily undermined by a lack of support from non-member states, and their cooperation is even more important and should be further facilitated. It is in the best interests of the EU to proactively promote biosecurity in the Suez Canal, to work with Egypt and the international maritime industry, and address this fundamental threat to the Mediterranean socio-ecological system. Given the difficulties in eradicating established marine invasive species, adaptive management efforts should aim to promote public awareness and education, to incentivize targeted fisheries, and to promote continuous removal from the natural environment [69].

Supplementary Materials: The following are available online at https:/ / www.mdpi.com/2077-131 2/9/3/325/s1.

Author Contributions: Conceptualization, P.K.; methodology, P.K., I.S., M.H.; formal analysis, P.K., I.S.; data curation, P.K., J.M.H.-S., I.S., D.K., C.A., L.H., N.C., Y.C., I.G., C.J.; writing—original draft preparation, P.K., S.E.R.; writing-review and editing, P.K., J.M.H.-S., I.S., D.K., M.H., E.A., S.K., C.A., L.H., N.C., M.C., Y.C., I.G., C.J., S.S., S.E.R.; visualization, P.K., S.S.; supervision, P.K., J.M.H.-S., I.S., D.K., S.E.R.; project administration, D.K.; funding acquisition, P.K., J.M.H.-S., D.K., S.E.R. All authors have read and agreed to the published version of the manuscript.

Funding: This research was funded by the LIFE financial instrument of the European UnionRELIONMED project [Grant Agreement LIFE16 NAT/CY/000832].

Institutional Review Board Statement: Not applicable.

Informed Consent Statement: Not applicable.

Conflicts of Interest: The authors declare no conflict of interest.

\section{References}

1. Simberloff, D.; Martin, J.-L.; Genovesi, P.; Maris, V.; Wardle, D.A.; Aronson, J.; Courchamp, F.; Galil, B.; García-Berthou, E.; Pascal, M. Impacts of biological invasions: What's what and the way forward. Trends Ecol. Evol. 2013, 28, 58-66. [CrossRef]

2. Seebens, H.; Blackburn, T.M.; Dyer, E.E.; Genovesi, P.; Hulme, P.E.; Jeschke, J.M.; Pagad, S.; Pyšek, P.; Winter, M.; Arianoutsou, M. No saturation in the accumulation of alien species worldwide. Nat. Commun. 2017, 8, 1-9. [CrossRef]

3. IUCN. Guidelines for the prevention of biodiversity loss caused by alien invasive species. In Secondary Guidelines for the Prevention of Biodiversity Loss Caused by Alien Invasive Species; IUCN: Gland, Switzerland, 2000.

4. Millenium Ecosystem Assessment. Ecosystems \& Human Well-Being; Island Press: Washington, DC, USA, 2005.

5. Brondizio, E.S.; Settele, J.; Díaz, S.; Ngo, H.T. Global Assessment Report on Biodiversity and Ecosystem Services of the Intergovernmental Science-Policy Platform on Biodiversity and Ecosystem Services; IPBES Secretariat: Bonn, Germany, 2019.

6. EASIN. Available online: https: / / easin.jrc.ec.europa.eu/ (accessed on 23 January 2021).

7. Katsanevakis, S.; Deriu, I.; D'amico, F.; Nunes, A.L.; Sanchez, S.P.; Crocetta, F.; Arianoutsou, M.; Bazos, I.; Christopoulou, A.; Curto, G. European alien species information network (EASIN): Supporting European policies and scientific research. Manag. Biol. Invasions 2015, 6, 147-157. [CrossRef]

8. Seebens, H.; Bacher, S.; Blackburn, T.M.; Capinha, C.; Dawson, W.; Dullinger, S.; Genovesi, P.; Hulme, P.E.; van Kleunen, M.; Kühn, I. Projecting the continental accumulation of alien species through to 2050. Glob. Chang. Biol. 2020, 27, 968-969. [CrossRef]

9. Essl, F.; Lenzner, B.; Bacher, S.; Bailey, S.; Capinha, C.; Daehler, C.; Dullinger, S.; Genovesi, P.; Hui, C.; Hulme, P.E.; et al. Drivers of future alien species impacts: An expert-based assessment. Glob. Chang. Biol. 2020, 26, 4880-4893. [CrossRef]

10. EC. Regulation No 1143/2014 of the European Parliament and of the Council of 22 October 2014 on the prevention and management of the introduction and spread of invasive alien species. In Secondary Regulation No 1143/2014 of the European Parliament and of the Council of 22 October 2014 on the Prevention and Management of the Introduction and Spread of Invasive Alien Species; European Commission: Strasbourg, France, 2014.

11. EC. Communication from the Commission to the European Parliament, the Council, the European Economic and Social Committee and the Committee of the Regions-EU Biodiversity Strategy for 2030 Bringing nature back into our lives. In Secondary Communication from the Commission to the European Parliament, the Council, the European Economic and Social Committee and the Committee of the Regions-EU Biodiversity Strategy for 2030 Bringing Nature Back into Our Lives; European Commission: Brussels, Belgium, 2020. 
12. Justo-Hanani, R.; Dayan, T. Risk regulation and precaution in Europe and the United States: The case of bioinvasion. Policy Sci. 2020, 54, 3-20. [CrossRef]

13. Tsiamis, K.; Azzurro, E.; Bariche, M.; Çinar, M.E.; Crocetta, F.; De Clerck, O.; Galil, B.; Gómez, F.; Hoffman, R.; Jensen, K.R. Prioritizing marine invasive alien species in the European Union through horizon scanning. Aquat. Conserv. Mar. Freshwat. Ecosyst. 2020, 30, 794-845. [CrossRef]

14. Tsiamis, K.; Zenetos, A.; Deriu, I.; Gervasini, E.; Cardoso, A.C. The native distribution range of the European marine nonindigenous species. Aquat. Invasions 2018, 13, 187-198. [CrossRef]

15. Azzurro, E.; Sbragaglia, V.; Cerri, J.; Bariche, M.; Bolognini, L.; Souissi, J.B.; Busoni, G.; Coco, S.; Chryssanthi, A.; Garrabou, J. The shifting distribution of Mediterranean fishes: A spatio-temporal assessment based on Local Ecological Knowledge. Glob. Chang. Biol. 2019, 25. [CrossRef] [PubMed]

16. Edelist, D.; Rilov, G.; Golani, D.; Carlton, J.T.; Spanier, E. Restructuring the Sea: Profound shifts in the world's most invaded marine ecosystem. Divers. Distrib. 2013, 19, 69-77. [CrossRef]

17. Corrales, X.; Coll, M.; Ofir, E.; Heymans, J.J.; Steenbeek, J.; Goren, M.; Edelist, D.; Gal, G. Future scenarios of marine resources and ecosystem conditions in the Eastern Mediterranean under the impacts of fishing, alien species and sea warming. Sci. Rep. 2018, 8, 14284. [CrossRef]

18. Zenetos, A.; Çinar, M.E.; Crocetta, F.; Golani, D.; Rosso, A.; Servello, G.; Shenkar, N.; Turon, X.; Verlaque, M. Uncertainties and validation of alien species catalogues: The Mediterranean as an example. Estuar. Coast. Shelf Sci. 2017, 191, 171-187. [CrossRef]

19. Albano, P.G.; Steger, J.; Bošnjak, M.; Dunne, B.; Guifarro, Z.; Turapova, E.; Hua, Q.; Kaufman, D.S.; Rilov, G.; Zuschin, M. Native biodiversity collapse in the eastern Mediterranean. Proc. R. Soc. B Biol. Sci. 2021, 288, 20202469. [CrossRef]

20. Bariche, M.; Torres, M.; Azzurro, E. The presence of the invasive Lionfish Pterois miles in the Mediterranean Sea. Mediterr. Mar. Sci. 2013, 14, 292-294. [CrossRef]

21. Golani, D.; Sonin, O. New records of the Red Sea fishes, Pterois miles (Scorpaenidae) and Pteragogus pelycus (Labridae) from the eastern Mediterranean Sea. Jap. J. Ichthyol. 1992, 39, 167-169.

22. Kletou, D.; Hall-Spencer, J.M.; Kleitou, P. A lionfish (Pterois miles) invasion has begun in the Mediterranean Sea. Mar. Biodivers. Rec. 2016, 9, 46. [CrossRef]

23. Jimenez, C.; Petrou, A.; Andreou, V.; Hadjioannou, L.; Wolf, W.; Koutsoloukas, N.; Alhaija, R.A.; QDivers, A.N.; Aquarium, O. Veni, vidi, vici: The successful establishment of the lionfish Pterois miles in Cyprus (Levantine Sea). Rapp. Comm. Int. Mer. Mediterr. 2016, 41, 417.

24. Azzurro, E.; Stancanelli, B.; Di Martino, V.; Bariche, M. Range expansion of the common lionfish Pterois miles (Bennett, 1828) in the Mediterranean Sea: An unwanted new guest for Italian waters. Bioinvasions Rec. 2017, 6, 95-98. [CrossRef]

25. Dimitriadis, C.; Galanidi, M.; Zenetos, A.; Corsini-Foka, M.; Giovos, I.; Karachle, P.K.; Fournari-Konstantinidou, I.; Kytino, E.; Issaris, Y.; Azzurro, E.; et al. Updating the occurrences of Pterois miles in the Mediterranean Sea, with considerations on thermal boundaries and future range expansion. Mediterr. Mar. Sci. 2020, 21, 62-69. [CrossRef]

26. Hixon, M.A.; Green, S.J.; Albins, M.A.; Akins, J.L.; Morris, J.A., Jr. Lionfish: A major marine invasion. Mar. Ecol. Prog. Ser. 2016, 558, 161-165. [CrossRef]

27. Roy, H.E.; Adriaens, T.; Aldridge, D.; Bacher, S.; Bishop, J.; Blackburn, T.M.; Branquart, E.; Brodie, J.; Carboneras, C.; Cook, E.J. Invasive Alien Species-Prioritising prevention efforts through horizon scanning: ENV. B. 2/ETU/2014/0016. In Secondary Invasive Alien Species-Prioritising Prevention Efforts through Horizon Scanning: ENVIRON. B. 2/ETU/2014/0016; European Commission: Luxembourg, 2015.

28. Kleitou, P.; Hall-Spencer, J.; Rees, S.; Sfenthourakis, S.; Demetriou, A.; Chartosia, N.; Jimenez, C.; Hadjioannou, L.; Petrou, A.; Christodoulides, Y. Tackling the lionfish invasion in the Mediterranean. The EU-LIFE RELIONMED Project: Progress and results. In 1st Mediterranean Symp Non-Indigenous Species; Langar, H., Ouerghi, A., Eds.; SPA/RAC: Antalya, Turkey, $2019 ;$;p. 65-70.

29. Kulbicki, M.; Beets, J.; Chabanet, P.; Cure, K.; Darling, E.; Floeter, S.R.; Galzin, R.; Green, A.; Harmelin-Vivien, M.; Hixon, M. Distributions of Indo-Pacific lionfishes Pterois spp. in their native ranges: Implications for the Atlantic invasion. Mar. Ecol. Prog. Ser. 2012, 446, 189-205. [CrossRef]

30. Morris, J.A.; Whitfield, P.E. Biology, Ecology, Control and Management of the Invasive Indo-Pacific Lionfish: An Updated Integrated Assessment; NOAA Technical Memorandum NOS NCCOS 99: Beaufort, NC, USA, 2009.

31. Goodbody-Gringley, G.; Eddy, C.; Pitt, J.M.; Chequer, A.D.; Smith, S.R. Ecological drivers of invasive lionfish (Pterois volitans and Pterois miles) distribution across mesophotic reefs in Bermuda. Front. Mar. Sci. 2019, 6, 258. [CrossRef]

32. Eddy, C.; Pitt, J.; Morris, J.A.; Smith, S.; Goodbody-Gringley, G.; Bernal, D. Diet of invasive lionfish (Pterois volitans and P. miles) in Bermuda. Mar. Ecol. Prog. Ser. 2016, 558, 193-206. [CrossRef]

33. Peake, J.; Bogdanoff, A.K.; Layman, C.A.; Castillo, B.; Reale-Munroe, K.; Chapman, J.; Dahl, K.; Patterson, W.F., III; Eddy, C.; Ellis, R.D. Feeding ecology of invasive lionfish (Pterois volitans and Pterois miles) in the temperate and tropical western Atlantic. Biol. Invasions 2018, 20, 2567-2597. [CrossRef]

34. Rojas-Vélez, S.; Tavera, J.; Acero, A. Unraveling lionfish invasion: Is Pterois volitans truly a morphologically novel predator in the Caribbean? Biol. Invasions 2019, 21, 1921-1931. [CrossRef]

35. Green, S.J.; Dilley, E.R.; Benkwitt, C.E.; Davis, A.C.; Ingeman, K.E.; Kindinger, T.L.; Tuttle, L.J.; Hixon, M.A. Trait-mediated foraging drives patterns of selective predation by native and invasive coral-reef fishes. Ecosphere 2019, 10, e02752. [CrossRef] 
36. Galloway, K.A.; Porter, M.E. Mechanical properties of the venomous spines of Pterois volitans and morphology among lionfish species. J. Exp. Biol. 2019, 222, jeb197905. [CrossRef]

37. Fogg, A.Q.; Brown-Peterson, N.J.; Peterson, M.S. Reproductive life history characteristics of invasive red lionfish (Pterois volitans) in the northern Gulf of Mexico. Bull. Mar. Sci. 2017, 93, 791-813. [CrossRef]

38. Ahrenholz, D.W.; Morris, J.A. Larval duration of the lionfish, Pterois volitans along the Bahamian Archipelago. Environ. Biol. Fishes 2010, 88, 305-309. [CrossRef]

39. DeRoy, E.M.; Scott, R.; Hussey, N.E.; MacIsaac, H.J. Density dependence mediates the ecological impact of an invasive fish. Divers. Distrib. 2020, 26, 867-880. [CrossRef]

40. Green, S.J.; Akins, J.L.; Maljković, A.; Côté, I.M. Invasive lionfish drive Atlantic coral reef fish declines. PLoS ONE 2012, 7. [CrossRef]

41. Côté, I.M.; Green, S.J.; Hixon, M.A. Predatory fish invaders: Insights from Indo-Pacific lionfish in the western Atlantic and Caribbean. Biol. Conserv. 2013, 164, 50-61. [CrossRef]

42. Albins, M.A.; Hixon, M.A. Invasive Indo-Pacific lionfish Pterois volitans reduce recruitment of Atlantic coral-reef fishes. Mar. Ecol. Prog. Ser. 2008, 367, 233-238. [CrossRef]

43. Benkwitt, C.E. Non-linear effects of invasive lionfish density on native coral-reef fish communities. Biol. Invasions 2015, 17, 1383-1395. [CrossRef]

44. Ingeman, K.E. Lionfish cause increased mortality rates and drive local extirpation of native prey. Mar. Ecol. Prog. Ser. 2016, 558, 235-245. [CrossRef]

45. Ballew, N.G.; Bacheler, N.M.; Kellison, G.T.; Schueller, A.M. Invasive lionfish reduce native fish abundance on a regional scale. Sci. Rep. 2016, 6, 32169. [CrossRef]

46. Layman, C.; Jud, Z.; Nichols, P. Lionfish alter benthic invertebrate assemblages in patch habitats of a subtropical estuary. Mar. Biol. 2014, 161, 2179-2182. [CrossRef]

47. Kindinger, T.L.; Albins, M.A. Consumptive and non-consumptive effects of an invasive marine predator on native coral-reef herbivores. Biol. Invasions 2017, 19, 131-146. [CrossRef]

48. Lesser, M.P.; Slattery, M. Phase shift to algal dominated communities at mesophotic depths associated with lionfish (Pterois volitans) invasion on a Bahamian coral reef. Biol. Invasions 2011, 13, 1855-1868. [CrossRef]

49. Slattery, M.; Lesser, M.P. Allelopathy in the tropical alga L obophora variegata (P haeophyceae): Mechanistic basis for a phase shift on mesophotic coral reefs? J. Phycol. 2014, 50, 493-505. [CrossRef] [PubMed]

50. Green, S.J.; Dulvy, N.K.; Brooks, A.M.; Akins, J.L.; Cooper, A.B.; Miller, S.; Côté, I.M. Linking removal targets to the ecological effects of invaders: A predictive model and field test. Ecol. Appl. 2014, 24, 1311-1322. [CrossRef]

51. Savva, I.; Chartosia, N.; Antoniou, C.; Kleitou, P.; Georgiou, A.; Stern, N.; Hadjioannou, L.; Jimenez, C.; Andreou, V.; Hall-Spencer, J.M. They are here to stay: The biology and ecology of lionfish (Pterois miles) in the Mediterranean Sea. J. Fish Biol. 2020, 97, 148-162. [CrossRef]

52. Dimitriou, A.C.; Chartosia, N.; Hall-Spencer, J.M.; Kleitou, P.; Jimenez, C.; Antoniou, C.; Hadjioannou, L.; Kletou, D.; Sfenthourakis, S. Genetic Data Suggest Multiple Introductions of the Lionfish (Pterois miles) into the Mediterranean Sea. Diversity 2019, 11, 149. [CrossRef]

53. Kleitou, P.; Savva, I.; Kletou, D.; Hall-Spencer, J.M.; Antoniou, C.; Christodoulides, Y.; Chartosia, N.; Hadjioannou, L.; Dimitriou, A.C.; Jimenez, C. Invasive lionfish in the Mediterranean: Low public awareness yet high stakeholder concerns. Mar. Policy 2019, 104, 66-74. [CrossRef]

54. Giovos, I.; Kleitou, P.; Paravas, V.; Marmara, D.; Romanidis-Kyriakidis, G.; Poursanidis, D. Citizen scientists monitoring the establishment and expansion of Pterois miles (Bennett, 1828) in the Aegean Sea, Greece. Cah. Biol. Mar. 2018, 59, 359-365.

55. Poursanidis, D.; Kalogirou, S.; Azzurro, E.; Parravicini, V.; Bariche, M.; zu Dohna, H. Habitat suitability, niche unfilling and the potential spread of Pterois miles in the Mediterranean Sea. Mar. Pollut. Bull. 2020, 154, 111054. [CrossRef]

56. Jimenez, C.; Patsalou, P.; Andreou, V.; Huseyinoglu, M.; Çiçek, B.; Hadjioannou, L.; Petrou, A. Out of sight, out of reach, out of mind: Invasive lionfish Pterois miles in Cyprus at depths beyond recreational diving limits. In 1st Mediterranean Symp Non-Indigenous Species; Langar, H., Ouerghi, A., Eds.; SPA/RAC: Antalya, Turkey, 2019; pp. 17-18.

57. Orejas, C.; Jiménez, C.; Gori, A.; Rivera, J.; Iacono, C.L.; Aurelle, D.; Hadjioannou, L.; Petrou, A.; Achilleos, K. Corals of Aphrodite: Dendrophyllia ramea Populations of Cyprus. In Mediterranean Cold-Water Corals: Past, Present and Future; Orejas, C., Jiménez, C., Eds.; Springer Nature Switzerland AG: Cham, Switzerland, 2019; Volume 9, pp. 257-260. ISBN 978-3-319-91607-1.

58. Zannaki, K.; Corsini-Foka, M.; Kampouris, T.E.; Batjakas, I.E. First results on the diet of the invasive Pterois miles (Actinopterygii: Scorpaeniformes: Scorpaenidae) in the Hellenic waters. Acta Ichthyol. Piscat. 2019, 49, 311-317. [CrossRef]

59. Agostino, D.D.; Jimenez, C.; Reader, T.; Hadjioannou, L.; Heyworth, S.; Aplikioti, M.; Argyrou, M.; Feary, D.A. Behavioural traits and feeding ecology of Mediterranean lionfish and naiveté of native species to lionfish predation. Mar. Ecol. Prog. Ser. 2020, 638, 123-135. [CrossRef]

60. Crocetta, F.; Shokouros-Oskarsson, M.; Doumpas, N.; Giovos, I.; Kalogirou, S.; Langeneck, J.; Tanduo, V.; Tiralongo, F.; Virgili, R.; Kleitou, P. Protect the natives to combat the aliens: Octopus vulgaris Cuvier, 1797 as a natural agent for the control of the lionfish invasion in the Mediterranean Sea? J. Mar. Sci. Eng. 2021, 9, 308. [CrossRef]

61. Bariche, M.; Kleitou, P.; Kalogirou, S.; Bernardi, G. Genetics reveal the identity and origin of the lionfish invasion in the Mediterranean Sea. Sci. Rep. 2017, 7, 1-6. [CrossRef] 
62. Stern, N.; Jimenez, C.; Huseyinoglu, M.F.; Andreou, V.; Hadjioannou, L.; Petrou, A.; Öztürk, B.; Golani, D.; Rothman, S.B. Constructing the genetic population demography of the invasive lionfish Pterois miles in the Levant Basin, Eastern Mediterranean. Mitochondrial DNA Part A 2019, 30, 249-255. [CrossRef] [PubMed]

63. Poursanidis, D. Ecological Niche Modeling of the the invasive lionfish Pterois miles (Bennett, 1828) in the Mediterranean Sea. In Proceedings of the 11th Panhellenic Symposium of Oceanography \& Fisheries, Mytiline, Greece, 13-17 May 2015.

64. Parravicini, V.; Azzurro, E.; Kulbicki, M.; Belmaker, J. Niche shift can impair the ability to predict invasion risk in the marine realm: An illustration using Mediterranean fish invaders. Ecol. Lett. 2015, 18, 246-253. [CrossRef] [PubMed]

65. D'Amen, M.; Azzurro, E. Lessepsian fish invasion in Mediterranean marine protected areas: A risk assessment under climate change scenarios. ICES J. Mar. Sci. 2020, 77, 388-397. [CrossRef]

66. Whitfield, P.E.; Muñoz, R.C.; Buckel, C.A.; Degan, B.P.; Freshwater, D.W.; Hare, J.A. Native fish community structure and Indo-Pacific lionfish Pterois volitans densities along a depth-temperature gradient in Onslow Bay, North Carolina, USA. Mar. Ecol. Prog. Ser. 2014, 509, 241-254. [CrossRef]

67. Harris, H.E.; Fogg, A.Q.; Gittings, S.R.; Ahrens, R.N.; Allen, M.S.; Patterson, W.F. Testing the efficacy of lionfish traps in the northern Gulf of Mexico. PLoS ONE 2020, 15, e0230985. [CrossRef] [PubMed]

68. Sutherland, W.J.; Barnard, P.; Broad, S.; Clout, M.; Connor, B.; Côté, I.M.; Dicks, L.V.; Doran, H.; Entwistle, A.C.; Fleishman, E. A 2017 horizon scan of emerging issues for global conservation and biological diversity. Trends Ecol. Evol. 2017, 32, 31-40. [CrossRef]

69. Kleitou, P.; Crocetta, F.; Giakoumi, S.; Giovos, I.; Hall-Spencer, J.M.; Kalogirou, S.; Kletou, D.; Moutopoulos, D.K.; Rees, S. Fishery reforms for the management of non-indigenous species. J. Environ. Manag. 2021, 280, 111690. [CrossRef] [PubMed]

70. Carr, M.H.; Neigel, J.E.; Estes, J.A.; Andelman, S.; Warner, R.R.; Largier, J.L. Comparing marine and terrestrial ecosystems: Implications for the design of coastal marine reserves. Ecol. Appl. 2003, 13, 90-107. [CrossRef]

71. Kinlan, B.P.; Gaines, S.D. Propagule dispersal in marine and terrestrial environments: A community perspective. Ecology 2003, 84, 2007-2020. [CrossRef]

72. Burgess, S.C.; Baskett, M.L.; Grosberg, R.K.; Morgan, S.G.; Strathmann, R.R. When is dispersal for dispersal? Unifying marine and terrestrial perspectives. Biol. Rev. 2016, 91, 867-882. [CrossRef]

73. Anderson, L.W. California's reaction to Caulerpa taxifolia: A model for invasive species rapid response. Biol. Invasions 2005, 7, 1003-1016. [CrossRef]

74. Willan, R.C.; Russell, B.C.; Murfet, N.B.; Moore, K.L.; McEnnulty, F.R.; Horner, S.K.; Hewitt, C.L.; Dally, G.M.; Campbell, M.L.; Bourke, S.T. Outbreak of Mytilopsis sallei (Recluz, 1849)(Bivalvia: Dreissenidae) in Australia. Molluscan Res. 2000, $20,25-30$. [CrossRef]

75. Katsanevakis, S.; Coll, M.; Fraschetti, S.; Giakoumi, S.; Goldsborough, D.; Mačić, V.; Mackelworth, P.; Rilov, G.; Stelzenmüller, V.; Albano, P.G. Twelve recommendations for advancing marine conservation in European and contiguous seas. Front. Mar. Sci. 2020, 7, 879. [CrossRef]

76. Early, R.; Bradley, B.A.; Dukes, J.S.; Lawler, J.J.; Olden, J.D.; Blumenthal, D.M.; Gonzalez, P.; Grosholz, E.D.; Ibañez, I.; Miller, L.P. Global threats from invasive alien species in the twenty-first century and national response capacities. Nat. Commun. 2016, 7, 1-9. [CrossRef]

77. Booy, O.; Robertson, P.; Moore, N.; Ward, J.; Roy, H.; Adriaens, T.; Shaw, R.; Valkenburg, J.; Wyn, G.; Bertolino, S.; et al. Using structured eradication feasibility assessment to prioritise the management of new and emerging invasive alien species in Europe. Glob. Chang. Biol. 2020, 26, 6235-6250. [CrossRef] [PubMed]

78. Mannino, A.M.; Borfecchia, F.; Micheli, C. Tracking Marine Alien Macroalgae in the Mediterranean Sea: The Contribution of Citizen Science and Remote Sensing. J. Mar. Sci. Eng. 2021, 9, 288.

79. Peyton, J.; Martinou, A.F.; Pescott, O.L.; Demetriou, M.; Adriaens, T.; Arianoutsou, M.; Bazos, I.; Bean, C.W.; Booy, O.; Botham, M. Horizon scanning for invasive alien species with the potential to threaten biodiversity and human health on a Mediterranean island. Biol. Invasions 2019, 21, 2107-2125. [CrossRef]

80. Peyton, J.M.; Martinou, A.F.; Adriaens, T.; Chartosia, N.; Karachle, P.K.; Rabitsch, W.; Tricarico, E.; Arianoutsou, M.; Bacher, S.; Bazos, I. Horizon scanning to predict and prioritize invasive alien species with the potential to threaten human health and economies on Cyprus. Front. Ecol. Evol. 2020, 8, 284. [CrossRef]

81. Giakoumi, S.; Katsanevakis, S.; Albano, P.G.; Azzurro, E.; Cardoso, A.C.; Cebrian, E.; Deidun, A.; Edelist, D.; Francour, P.; Jimenez, C. Management priorities for marine invasive species. Sci. Total Environ. 2019, 688, 976-982. [CrossRef]

82. Boon, P.J.; Clarke, S.A.; Copp, G.H. Alien species and the EU Water Framework Directive: A comparative assessment of European approaches. Biol. Invasions 2020, 22, 1497-1512. [CrossRef]

83. Roy, H.E.; Bacher, S.; Essl, F.; Adriaens, T.; Aldridge, D.C.; Bishop, J.D.; Blackburn, T.M.; Branquart, E.; Brodie, J.; Carboneras, C. Developing a list of invasive alien species likely to threaten biodiversity and ecosystems in the European Union. Glob. Chang. Biol. 2019, 25, 1032-1048. [CrossRef]

84. Rilov, G.; Mazaris, A.D.; Stelzenmüller, V.; Helmuth, B.; Wahl, M.; Guy-Haim, T.; Mieszkowska, N.; Ledoux, J.-B.; Katsanevakis, S. Adaptive marine conservation planning in the face of climate change: What can we learn from physiological, ecological and genetic studies? Glob. Ecol. Conserv. 2019, 17, e00566. [CrossRef]

85. Bonanno, G.; Orlando-Bonaca, M. Non-indigenous marine species in the Mediterranean Sea-Myth and reality. Environ. Sci. Policy 2019, 96, 123-131. [CrossRef] 
86. Katsanevakis, S.; Bogucarskis, K.; Gatto, F.; Vandekerkhove, J.; Deriu, I.; Cardoso, A.C. Building the European Alien Species Information Network (EASIN): A novel approach for the exploration of distributed alien species data. Bioinvasions Rec. 2012, 1, 235-245. [CrossRef]

87. Tsiamis, K.; Palialexis, A.; Stefanova, K.; Gladan, Ž.N.; Skejić, S.; Despalatović, M.; Cvitković, I.; Dragičević, B.; Dulčić, J.; Vidjak, O. Non-indigenous species refined national baseline inventories: A synthesis in the context of the European Union's Marine Strategy Framework Directive. Mar. Pollut. Bull. 2019, 145, 429-435. [CrossRef]

88. Murillas-Maza, A.; Uyarra, M.C.; Papadopoulou, K.N.; Smith, C.J.; Gorjanc, S.; Klancnik, K.; Paramana, T.; Chalkiadaki, O.; Dassenakis, M.; Pavicic, M. Programmes of measures of the marine strategy framework directive: Are they contributing to achieving good environmental status in the Mediterranean? Mar. Pollut. Bull. 2020, 161, 111715. [CrossRef] [PubMed]

89. Azzurro, E.; Bolognini, L.; Dragičević, B.; Drakulović, D.; Dulčić, J.; Fanelli, E.; Grati, F.; Kolitari, J.; Lipej, L.; Magaletti, E. Detecting the occurrence of indigenous and non-indigenous megafauna through fishermen knowledge: A complementary tool to coastal and port surveys. Mar. Pollut. Bull. 2019, 147, 229-236. [CrossRef] [PubMed]

90. Giovos, I.; Kleitou, P.; Poursanidis, D.; Batjakas, I.; Bernardi, G.; Crocetta, F.; Doumpas, N.; Kalogirou, S.; Kampouris, T.E.; Keramidas, I. Citizen-science for monitoring marine invasions and stimulating public engagement: A case project from the eastern Mediterranean. Biol. Invasions 2019, 21, 3707-3721. [CrossRef]

91. Kleitou, P.; Giovos, I.; Wolf, W.; Crocetta, F. On the importance of citizen-science: The first record of Goniobranchus obsoletus (Rüppell and Leuckart, 1830) from Cyprus (Mollusca: Gastropoda: Nudibranchia). Bioinvasions Rec. 2019, 8, 252-257. [CrossRef]

92. Crocetta, F.; Agius, D.; Balistreri, P.; Bariche, M.; Bayhan, Y.K.; Çakir, M.; Ciriaco, S.; Corsini-Foka, M.; Deidun, A.; El Zrelli, R. New mediterranean biodiversity records (October 2015). Mediterr. Mar. Sci. 2015, 16, 682-702. [CrossRef]

93. Carballo-Cárdenas, E.C.; Tobi, H. Citizen science regarding invasive lionfish in Dutch Caribbean MPAs: Drivers and barriers to participation. Ocean Coast. Manag. 2016, 133, 114-127. [CrossRef]

94. Encarnação, J.; Morais, P.; Teodosio, M.A. Citizen science and biological invasions: A review. Front. Environ. Sci. $2020,8,303$.

95. Katsanevakis, S.; Poursanidis, D.; Hoffman, R.; Rizgalla, J.; Rothman, S.B.-S.; Levitt-Barmats, Y.; Hadjioannou, L.; Trkov, D.; Garmendia, J.M.; Rizzo, M. Unpublished Mediterranean records of marine alien and cryptogenic species. Bioinvasions Rec. 2020, 9, 165-182. [CrossRef]

96. Kelly, R.P.; Closek, C.J.; O’Donnell, J.L.; Kralj, J.E.; Shelton, A.O.; Samhouri, J.F. Genetic and manual survey methods yield different and complementary views of an ecosystem. Front. Mar. Sci. 2017, 3, 283. [CrossRef]

97. Aglieri, G.; Baillie, C.; Mariani, S.; Cattano, C.; Calò, A.; Turco, G.; Spatafora, D.; Di Franco, A.; Di Lorenzo, M.; Guidetti, P. Environmental DNA effectively captures functional diversity of coastal fish communities. Mol. Ecol. 2020. [CrossRef] [PubMed]

98. Dickinson, J.L.; Zuckerberg, B.; Bonter, D.N. Citizen science as an ecological research tool: Challenges and benefits. Annu. Rev. Ecol. Evol. Syst. 2010, 41, 149-172. [CrossRef]

99. Ward, R.C.; Loftis, J.C.; McBride, G.B. The "data-rich but information-poor" syndrome in water quality monitoring. Environ. Manag. 1986, 10, 291-297. [CrossRef]

100. Wilding, T.A.; Gill, A.B.; Boon, A.; Sheehan, E.; Dauvin, J.C.; Pezy, J.-P.; O’beirn, F.; Janas, U.; Rostin, L.; De Mesel, I. Turning off the DRIP ('Data-rich, information-poor')-rationalising monitoring with a focus on marine renewable energy developments and the benthos. Renew. Sustain. Energy Rev. 2017, 74, 848-859. [CrossRef]

101. García-Barón, I.; Giakoumi, S.; Santos, M.B.; Granado, I.; Louzao, M. The value of time-series data for conservation planning. J. Appl. Ecol. 2020, 58, 608-619. [CrossRef]

102. Rotter, A.; Klun, K.; Francé, J.; Mozetič, P.; Orlando-Bonaca, M. Non-indigenous species in the Mediterranean Sea: Turning from pest to source by developing the 8Rs model, a new paradigm in pollution mitigation. Front. Mar. Sci. 2020, 7, 178. [CrossRef]

103. Pyšek, P.; Hulme, P.E.; Simberloff, D.; Bacher, S.; Blackburn, T.M.; Carlton, J.T.; Dawson, W.; Essl, F.; Foxcroft, L.C.; Genovesi, P. Scientists' warning on invasive alien species. Biol. Rev. 2020, 95, 1511-1534. [CrossRef]

104. Katsanevakis, S.; Zenetos, A.; Belchior, C.; Cardoso, A.C. Invading European Seas: Assessing pathways of introduction of marine aliens. Ocean Coast. Manag. 2013, 76, 64-74. [CrossRef]

105. Galil, B.; Marchini, A.; Occhipinti-Ambrogi, A.; Ojaveer, H. The enlargement of the Suez Canal—Erythraean introductions and management challenges. Manag. Biol. Invasions 2017, 8, 141-152. [CrossRef]

106. Galil, B.S.; Boero, F.; Campbell, M.L.; Carlton, J.T.; Cook, E.; Fraschetti, S.; Gollasch, S.; Hewitt, C.L.; Jelmert, A.; Macpherson, E. 'Double trouble': The expansion of the Suez Canal and marine bioinvasions in the Mediterranean Sea. Biol. Invasions 2015, 17, 973-976. [CrossRef]

107. Galil, B.S.; Mienis, H.K.; Hoffman, R.; Goren, M. Non-indigenous species along the Israeli Mediterranean coast: Tally, policy, outlook. Hydrobiologia 2020. [CrossRef] 